\title{
Evaluation of a Small-Molecule Compound, N-Acetylcysteine, for the Management of Bacterial Spot of Tomato Caused by Copper-Resistant Xanthomonas perforans
}

\author{
Kang Qiao, ${ }^{1,2}$ Qingchun Liu, ${ }^{1}$ Ye Xia, ${ }^{3}$ and Shouan Zhang, ${ }^{1, \dagger}$ \\ ${ }^{1}$ Tropical Research and Education Center, Department of Plant Pathology, University of Florida, IFAS, Homestead, FL 33031, \\ U.S.A. \\ ${ }^{2}$ Key Laboratory of Pesticide Toxicology \& Application Technique, College of Plant Protection, Shandong Agricultural Univer- \\ sity, Tai' an, Shandong 271018, P.R. China \\ ${ }^{3}$ Department of Plant Pathology, Ohio State University, Columbus, OH 43210, U.S.A.
}

\begin{abstract}
Bacterial spot caused by Xanthomonas spp. is one of the major diseases in tomato. Xanthomonas perforans is the main pathogen of bacterial spot on tomato in Florida. Currently, application of copper fungicides is the primary measure used to manage this disease. However, the development of copper resistance in $X$. perforans and accumulation of copper in the environment are major concerns for excessive use of copper-based products in agriculture. Due to its antibacterial properties and low environmental impact, $\mathrm{N}$-acetylcysteine (NAC), a small molecule commonly used in medicine for human bacterial diseases, has been studied in agriculture for the control of plant bacterial pathogens, including X. citri and Xylella fastidiosa. This study evaluated the effect of NAC alone and in combination with copper on a copper-resistant $X$. perforans strain in vitro and its ability to

copper-resistant $X$. perforans to copper in vitro when application of NAC was followed by copper application after $6 \mathrm{~h}$. In greenhouse assays, NAC applied alone or in combination with copper significantly $(P<0.05)$ reduced the disease severity of bacterial spot on tomato compared with the untreated control. NAC at $100 \mathrm{mg} \mathrm{liter}^{-1}+$ copper at $300 \mathrm{mg} \mathrm{liter}^{-1}$ consistently exhibited synergistic effects against bacterial spot. In the field trials, NAC at $1,000 \mathrm{mg} \mathrm{liter}^{-1}+$ copper at $150 \mathrm{mg} \mathrm{liter}^{-1}$ significantly reduced disease severity compared with the untreated control. Results from this study demonstrated that NAC significantly reduced the disease severity of bacterial spot of tomato and enhanced the efficacy of copper against copper-resistant $X$. perforans, indicating that NAC could be applied for the effective management of bacterial spot of tomato.
\end{abstract} control bacterial spot of tomato under greenhouse and field conditions. In vitro, the minimum inhibitory concentration of NAC against the $X$. perforans strain was $2,048 \mathrm{mg}$ liter $^{-1}$. NAC increased sensitivity of the
Keywords: copper, integrated disease management, small-molecule compound, synergistic effect
Tomato (Solanum lycopersicum) is an economically important vegetable crop in the United States. Tomato production is affected by various diseases, including bacterial spot, a disease caused by four bacterial species of Xanthomonas (i.e., Xanthomonas vesicatoria, X. euvesicatoria, X. perforans, and X. gardneri) (Jones et al. 2004). In Florida, X. perforans is the pathogen causing bacterial spot disease in tomato fields (Horvath et al. 2012; Vallad et al. 2013). Typical symptoms of bacterial spot of tomato include necrotic lesions, circular spots on leaves, and, in some cases, spots and sunscald due to defoliation caused by this disease, which significantly decrease tomato fruit yield and quality. When conditions are highly favorable for disease development, bacterial spot can reduce tomato yield up to $50 \%$ (Louws et al. 2001).

Bacterial spot of tomato is difficult to control because the pathogen population evolves rapidly in fields, resulting in frequent race

${ }^{\dagger}$ Corresponding author: S. Zhang; szhang0007@ufl.edu

Funding: This study was supported by the United States Department of Agriculture (USDA) Agricultural Marketing Service through the Florida Department of Agriculture and Consumer Services Specialty Crop Block Grant project (award number USDA-AMS-SCBGP-2018).

The related opinions, findings, conclusions, or recommendations presented in this publication are those of the authors and do not necessarily reflect the view of the USDA.

Ethical approval: This article does not contain any studies with human participants or animals performed by any of the authors.

The author(s) declare no conflict of interest.

Accepted for publication 24 June 2020.

(C) 2021 The American Phytopathological Society changes (Potnis et al. 2015; Stall et al. 2009). Currently, chemical control using copper-based bactericides is the most common strategy for managing bacterial spot of tomato (Jones et al. 2007). However, due to the development of copper-resistant Xanthomonas strains, adequate control with copper-based bactericides is rare, even with multiple applications (Abrahamian et al. 2019). On the other hand, frequent use of copper has resulted in the development of resistance to copper in Xanthomonas spp. Moreover, the accumulation of copper in soils and ground water has adversely affected the environment and human health (Lamichhane et al. 2018; Pietrzak and McPhail 2004). Therefore, it is imperative to explore alternatives to copper for sustainable management of bacterial spot of tomato.

Small molecules are defined as organic compounds with molecular weight of no more than 900 Daltons; their antimicrobial properties have long been known in traditional and modern medicine (Han et al. 2015; Shi et al. 2019). Recently, antibacterial activities of some small molecules have been investigated in agriculture (Muranaka et al. 2013; Qiao et al. 2020; Xie et al. 2018). Worthington et al. (2012) reported the suppression activity of 2-aminoimidazole combined with copper hydroxide against bacterial spot of pepper caused by $X$. euvesicatoria in vitro and in field experiments, with no significant differences compared with a copper hydroxide + mancozeb treatment. Singh et al. (2018) demonstrated that citronellal at $75 \mu \mathrm{M}$ effectively reduced bacterial blight of rice caused by $X$. oryzae pv. oryzae. Our previous study showed that 3 -indolylacetonitrile at $1,000 \mathrm{mg}$ liter $^{-1}$ significantly reduced the disease severity of bacterial spot of tomato and improved control efficacy of copper against $X$. perforans under greenhouse conditions (Liu et al. 2019). Application of small-molecule compounds could be a promising alternative in management of bacterial spot of tomato.

$\mathrm{N}$-acetylcysteine $\left(\mathrm{C}_{5} \mathrm{H}_{9} \mathrm{NO}_{3} \mathrm{~S}\right.$, molecular weight: 163.19) (NAC) is a thiol compound that has been used as an antibacterial agent and inhibitor of biofilm formation in bacteria (Deepmala et al. 2015). Biofilm formation by plant bacterial pathogens plays an 
important role in disease development because it is associated with epiphytic survival and pathogenicity (Rigano et al. 2007). Applying NAC is a common strategy in medicine to inhibit the biofilm formation of human bacterial pathogens. Recently, NAC has been used in agriculture to control plant diseases caused by pathogenic bacteria. Muranaka et al. (2013) showed, for the first time, the antibacterial effect of NAC against Xylella fastidiosa. On the other hand, it has been reported that NAC can lessen copper toxicity by promoting phenolic acids to support the antioxidant defense system in wheat roots (Colak et al. 2019). Thus, we hypothesized that applying NAC could be a promising strategy for the management of copper-resistant $X$. perforans strains and the combination of NAC with copper may lead to a reduction of copper use. The objectives of this study were to investigate the in vitro effect of NAC, alone or in combination with copper, on the inhibition of the copper-resistant $X$. perforans and also its efficacy for the management of bacterial spot of tomato under greenhouse and field conditions.

\section{Materials and Methods}

Preparation of test chemicals. NAC ( $\geq 99 \%$ thin-layer chromatography; Sigma-Aldrich, St. Louis, MO. U.S.A.) and $\mathrm{CuSO}_{4}$ (Sigma-Aldrich) were dissolved in sterile distilled water to make stock solutions with a concentration of $1.0 \times 10^{4} \mathrm{mg} \mathrm{liter}^{-1}$ and stored at $4{ }^{\circ} \mathrm{C}$ prior to use. Copper hydroxide (Kocide 3000; DuPont, Wilmington, DE, U.S.A.) was used as a standard copper treatment in the greenhouse and field experiments.

Bacterial strain and storage. An isolate named QL was characterized to be a strain of $X$. perforans based on biochemical tests and molecular identification. It was isolated from symptomatic leaves of tomato plants in Homestead, FL and used throughout this study. Copper resistance of the $X$. perforans strain was determined by streaking a loopful from a $X$. perforans suspension onto nutrient agar plates amended with $\mathrm{CuSO}_{4}$ at concentrations up to $400 \mathrm{mg} \mathrm{li}-$ $\operatorname{ter}^{-1}$ (Basim et al. 2005; Behlau et al. 2012). The bacterial strain was stored in $30 \%$ glycerol at $-80^{\circ} \mathrm{C}$; bacterial cells were taken from the storage, streaked on nutrient agar (NA; Becton Dickinson, Sparks, MD, U.S.A.) plates, and incubated for $24 \mathrm{~h}$ at $28^{\circ} \mathrm{C}$. A single colony was transferred from the NA plates to $40 \mathrm{ml}$ of nutrient broth (NB; Himedia Laboratories, Mumbai, India) and incubated overnight at $28^{\circ} \mathrm{C}$ with agitation at $110 \mathrm{rpm}$. Bacterial suspensions were prepared in sterile distilled water to obtain $5.0 \times 10^{8} \mathrm{CFU} \mathrm{m}{ }^{-1}$ based on an optical density at $600 \mathrm{~nm}$ of 0.2 (4802 UV-VIS Spectrometer; Dayton, U.S.A.).

Determination of minimal inhibitory concentration of NAC. The minimal inhibitory concentration (MIC) of NAC was determined based on a broth microdilution assay following the standard guidelines (Clinical and Laboratory Standards Institute 2008). QL of $X$. perforans was incubated overnight in 50- $\mathrm{ml}$ centrifuge tubes (Corning, NY, U.S.A.) containing $40 \mathrm{ml}$ of $\mathrm{NB}$ at $28^{\circ} \mathrm{C}$ with agitation at $110 \mathrm{rpm}$. The bacterial cultures were diluted to $5.0 \times 10^{8} \mathrm{CFU}$ $\mathrm{ml}^{-1}$, as described previously. The $X$. perforans suspension $(100 \mu \mathrm{l})$ was added to individual 96-well plates containing $100 \mu \mathrm{l}$ of NB media with varied NAC concentrations (final concentrations of $16,32,64,128,256,512,1,024,2,048,4,096$, and 8,192 mg liter $^{-1}$ ). After incubation at $28^{\circ} \mathrm{C}$ for $24 \mathrm{~h}$, an aliquot of $20 \mu \mathrm{l}$ of the suspension was taken from each well for serial dilution and plated on NA media plates. The plates were incubated at $28^{\circ} \mathrm{C}$ for $24 \mathrm{~h}$ and the bacterial colonies grown on the plates were counted. MIC was defined as the minimum concentration resulting in no bacterial growth. After MIC was determined, an aliquot of $20 \mu \mathrm{l}$ of suspension from all wells with no visible bacterial growth was applied on each NA plate to confirm results. The bacterial suspension without NAC was used as the positive control and the uninoculated medium was used as the negative control. The MIC of copper $\left(\mathrm{CuSO}_{4}\right)$ alone was also determined with the same method and concentrations used for NAC. Each treatment consisted of three replicates and the assay was repeated twice.

Combination effect of $\mathrm{NAC}$ and copper in vitro. Antibacterial activities of NAC in combination with copper were determined in vitro using the MIC assay, as previously described. The combination effect of NAC and copper was determined by two methods: the addition of both compounds at the same time $(0 \mathrm{~h})$ and addition of copper $3,6,9$, or $12 \mathrm{~h}$ after the application of NAC. NAC at six concentrations $\left(32,64,128,256,512\right.$, and $\left.1,024 \mathrm{mg} \mathrm{liter}^{-1}\right)$ was tested in combination with five concentrations of copper $(64,128$, 256, 512, and 1,024 mg liter ${ }^{-1}$ ). The NA medium plates were incubated at $28^{\circ} \mathrm{C}$ for $24 \mathrm{~h}$. The same method was used as described previously. Each treatment consisted of three replicates and the assay was repeated twice. Because the results from all MIC assays were the same, data from one assay were provided.

Greenhouse experiments. The effect of NAC for the control of bacterial spot of tomato was investigated in greenhouse experiments at the Tropical Research and Education Center (TREC), University of Florida in Homestead, FL. There were nine treatments: untreated control, NAC at 100 and 1,000 mg liter ${ }^{-1}$, copper (Kocide 3000) at 150 and $300 \mathrm{mg} \mathrm{liter}^{-1}, \mathrm{NAC}$ at $100 \mathrm{mg} \mathrm{liter}^{-1}+$ copper at $150 \mathrm{mg}$ liter $^{-1}, \mathrm{NAC}$ at $100 \mathrm{mg} \mathrm{liter}^{-1}+$ copper at $300 \mathrm{mg} \mathrm{liter}^{-1}, \mathrm{NAC}$ at $1,000 \mathrm{mg} \mathrm{liter}{ }^{-1}+$ copper at $150 \mathrm{mg} \mathrm{liter}^{-1}$, and NAC at $1,000 \mathrm{mg}$ liter $^{-1}+$ copper at $300 \mathrm{mg} \mathrm{liter}^{-1}$. All treatments were applied once as foliar sprays onto both sides of the tomato leaves (cultivar Florida 47, three- to four-true-leaf stage) until run-off. Treatments were allowed to air dry on the leaf surface completely before inoculation, which took approximately 2 to $3 \mathrm{~h}$. Tomato plants were inoculated with a bacterial suspension $\left(1.0 \times 10^{8} \mathrm{CFU} \mathrm{ml}{ }^{-1}\right)$ of the copperresistant $X$. perforans strain by spraying both sides of the leaves with a hand-held mister until run-off. Both surfaces of the leaves of each plant were inoculated. The inoculation was made on three fully developed leaves at a similar developmental stage from each plant. The inoculated plants were placed in the growth chamber in which high (above $90 \%$ ) relative humidity was maintained. After incubation overnight at $25 \pm 2{ }^{\circ} \mathrm{C}$, the plants were removed from the chamber and transferred to the greenhouse, where the tomato plants were subjected to natural light ( $12 \mathrm{~h}$ each of light and darkness) at an average day and night temperature of 30 and $21^{\circ} \mathrm{C}$, respectively. The tomato plants were watered daily to the soil to avoid wetting the foliage. Disease severity of bacterial spot was rated by estimating the percentage of leaf area with typical symptoms of bacterial spot on three inoculated leaves of each plant at 7 to 10 days after the inoculation. All treatments were arranged in a randomized complete block design with six replicates, one plant for each replicate. The experiment was repeated twice.

Field experiments. Three field trials were conducted at TREC in Homestead, FL during 2018 to 2020. On 3 December 2018 (experiment 1), 25 March 2019 (experiment 2), and 19 November 2019 (experiment 3), 4-week-old seedlings of tomato were transplanted into the raised beds covered with black polyethylene mulch. Tomato Florida 47 was used in experiment 1 and Red Bounty was planted in experiments 2 and 3 . The beds were $0.8 \mathrm{~m}$ wide and centered $1.8 \mathrm{~m}$ apart. Tomato plants were transplanted at $0.6-\mathrm{m}$ spacing in a single bed of 8.2 to $8.5 \mathrm{~m}$ in each plot. Irrigation and fertilization were provided through two drip tapes passing by both sides of the plants on each bed to ensure the optimal requirements for tomato growth and production. A granular fertilizer 10-4.4-8.3 (N-P-K; Helena Chemical Co., Homestead, FL, U.S.A.) at $560 \mathrm{~kg} \mathrm{ha}^{-1}$ was applied to the soil before the beds were prepared; and a liquid fertilizer 7-0-5.8 (N-P-K; Helena Chemical Co.) at $8 \mathrm{~kg} \mathrm{ha}^{-1}$ was applied through drip injection each week after transplanting. Other agronomical practices were conducted according to current tomato production standards (Freeman et al. 2016). All field experiments were conducted in a randomized complete block design with four replications per treatment, and each replicate contained six plants.

Starting on 19 December 2018, 11 April 2019, and 11 December 2019 , the following treatments were applied to the plants weekly by foliar sprays (eight applications in total): NAC at 500 and 1,000 mg liter ${ }^{-1}$, copper (Kocide 3000) at $630 \mathrm{mg} \mathrm{liter}^{-1}$, and the water control for experiment 1 ; and NAC at 1,000 $\mathrm{mg} \mathrm{liter}^{-1}$, copper at $630 \mathrm{mg} \mathrm{li-}$ ter $^{-1}$, copper at $150 \mathrm{mg} \mathrm{liter}^{-1}$ in combination with NAC at $1,000 \mathrm{mg}$ liter $^{-1}$, and the water control for experiments 2 and 3. On 4 January 2019, 12 April 2019, and 18 December 2019, all plants in each plot were spray inoculated with a bacterial suspension of the copper-resistant 
$X$. perforans at $1.0 \times 10^{8} \mathrm{CFU} \mathrm{ml}^{-1}$ prepared from 24-h cultures on NA. Briefly, the bacteria were streaked on NA plates and incubated at $28^{\circ} \mathrm{C}$ for $24 \mathrm{~h}$. The bacterial cells were gently removed into sterile water and the bacterial concentration was adjusted with sterile water to $1.0 \times 10^{8} \mathrm{CFU}$ $\mathrm{ml}^{-1}$ for inoculation. Disease severity was rated by visually estimating the percentage of bacterial spot lesions on the leaves for each plant, except for the two plants at both ends in each plot (i.e., four plants per plot), 7 to 10 days after the inoculation and continued once a week until 1 week after the last treatments. For experiment 1, all plants in the field plots were rated for foliar disease severity three times (on 24 January and 12 and 22 February 2019) and area under the disease progress curve (AUDPC) over time was calculated for the field data using the trapezoidal method (Jeger 2004). In experiment 2, due to heavy infection of tomato yellow leaf curl virus (TYLCV), foliar disease severity was rated only once, on 22 April 2019. For experiment 3, all plants in the field plots were rated for foliar disease severity five times (2, 9, 17, 24, and 30 January 2020) and AUDPC was calculated as previously described. Vigor of the plants was rated following a 1-to-5 scale, where $5=$ vigorous growth, $4=$ slight yellowing and a little short, $3=$ more yellowing and shorter, and 2 and $1=$ growing much more poorly than normal. Mature fruit were harvested according to the Florida tomato production standards (Paret et al. 2013).

Statistical analysis. For the greenhouse experiments, the Colby formula was used to test whether there is a synergistic effect between NAC and copper, as described by Gisi (1996). Data were transformed to the percent reduction from the untreated control, and the synergistic or antagonistic responses of the two treatments were calculated according to the Colby equation: $E=X+Y-X Y / 100$, where $E$ is the expected growth inhibition (\%) by NAC + copper and $X$ and $Y$ are observed growth inhibition (\%) with NAC and copper, respectively (Colby 1967). If the expected response is less than the observed, the combination is synergistic; if greater than observed, it is antagonistic.

Due to differences in treatment and rating date in the three field trials across years, the data across years were not combined for analysis. Analysis of variance was conducted for the data using SPSS (version 17.0; SPSS Statistics, Chicago, IL, U.S.A.) and the significance of the treatments was determined using the Student-Newman-Keuls test at $P=0.05$.

\section{Results}

Determination of MIC of NAC and copper. In the NB medium, the MIC was 2,048 $\mathrm{mg} \mathrm{liter}^{-1}$ for both NAC and copper against the copper-resistant $X$. perforans strain (Table 1). Different assays were conducted to determine the combined effect of NAC and copper: addition of both compounds at the same time, and addition of copper at $3,6,9$, or $12 \mathrm{~h}$ after application of NAC. There was no effect on bacterial growth when adding both compounds at the same time $(0 \mathrm{~h})$ or adding copper $3 \mathrm{~h}$ after the application of NAC (Table 1). However, adding copper $6 \mathrm{~h}$ after the application of NAC at $128 \mathrm{mg} \mathrm{liter}^{-1} \mathrm{de}-$ creased the MIC of copper against the copper-resistant $X$. perforans

Table 1. Minimum inhibitory concentration (MIC) values of copper against the Xanthomonas perforans in nutrient broth $(\mathrm{NB})\left(24 \mathrm{~h}, 28^{\circ} \mathrm{C}\right)$ at different times after application of $\mathrm{N}$-acetylcysteine (NAC) ${ }^{\mathrm{z}}$

\begin{tabular}{lccccc}
\hline & \multicolumn{5}{c}{$\begin{array}{c}\text { Copper MIC }\left(\mathbf{m g ~ l i t e r}^{-\mathbf{1}}\right) \text { at time } \\
\text { post-application of NAC }\end{array}$} \\
\cline { 2 - 6 } NAC concentration $\left(\mathbf{m g ~ l i t e r}^{-\mathbf{1}}\right)$ & $\mathbf{0 ~ h}$ & $\mathbf{3 ~ h}$ & $\mathbf{6 ~ h}$ & $\mathbf{9} \mathbf{~ h}$ & $\mathbf{1 2} \mathbf{~ h}$ \\
\hline 32 & + & + & + & + & + \\
64 & + & + & + & + & + \\
128 & + & + & 1,024 & + & + \\
256 & + & + & 1,024 & 1,024 & 1,024 \\
512 & + & + & 1,024 & 1,024 & 1,024 \\
1,024 & + & + & 1,024 & 1,024 & 1,024 \\
\hline
\end{tabular}

${ }^{\mathrm{z}}$ MIC of both NAC and copper was 2,048 $\mathrm{mg} \mathrm{liter}^{-1}$. Six dilutions of NAC $\left(32,64,128,256,512\right.$, and $\left.1,024 \mathrm{mg} \mathrm{liter}^{-1}\right)$ were tested in combination with five concentrations of copper $\left(64,128,256,512\right.$, and 1,024 $\left.\mathrm{mg} \mathrm{liter}^{-1}\right) ;+$ indicates that visible growth of the bacteria was observed. from 2,048 $\mathrm{mg} \mathrm{liter}^{-1}$ to $1,024 \mathrm{mg} \mathrm{liter}^{-1}$. Adding copper 9 and $12 \mathrm{~h}$ after the application of NAC at $256 \mathrm{mg} \mathrm{liter}^{-1}$ decreased the MIC of copper against the copper-resistant $X$. perforans from 2,048 mg liter ${ }^{-1}$ to $1,024 \mathrm{mg} \mathrm{liter}^{-1}$.

Greenhouse experiments. All treatments significantly $(P<0.05)$ reduced the disease severity of bacterial spot when compared with the untreated control in both greenhouse experiments (Table 2). In experiment 1 , the treatment of NAC at $1,000 \mathrm{mg} \mathrm{liter}^{-1}+$ copper at $300 \mathrm{mg} \mathrm{liter}^{-1}$ was most effective in reducing bacterial spot disease severity, with a disease reduction of $63.1 \%$ compared with the untreated control. Other combination treatments of NAC + copper were less effective in reducing disease severity of bacterial spot but superior to $\mathrm{NAC}$ at $100 \mathrm{mg} \mathrm{liter}^{-1}$ and copper at $150 \mathrm{mg} \mathrm{liter}^{-1}$. In experiment 2 , all of the treatments significantly reduced bacterial spot disease severity when compared with the nontreated. NAC at 1,000 $\mathrm{mg} \mathrm{liter}^{-1}+$ copper at $300 \mathrm{mg} \mathrm{liter}^{-1}$, NAC at $1,000 \mathrm{mg} \mathrm{liter}^{-1}+$ copper at $150 \mathrm{mg}$ liter $^{-1}$, NAC at $100 \mathrm{mg} \mathrm{liter}^{-1}+$ copper at $300 \mathrm{mg} \mathrm{liter}^{-1}$, and NAC at $1,000 \mathrm{mg} \mathrm{liter}^{-1}$ were all effective in reducing disease of bacterial spot, followed by NAC at $100 \mathrm{mg} \mathrm{liter}^{-1}+$ copper at $150 \mathrm{mg} \mathrm{liter}^{-1}$. According to the Colby formula, NAC at $100 \mathrm{mg} \mathrm{liter}^{-1}+$ copper at $300 \mathrm{mg}$ liter $^{-1}$ displayed a synergistic effect in both experiments.

Field experiments. In field experiment 1 , copper at $630 \mathrm{mg} \mathrm{liter}^{-1}$ significantly $(P<0.05)$ reduced AUDPC compared with the untreated control (Table 3). NAC at 500 and $1,000 \mathrm{mg} \mathrm{liter}^{-1}$ each reduced AUDPC by 9.7 to $13.3 \%$ but not significantly compared with copper at $630 \mathrm{mg} \mathrm{liter}^{-1}$ or the untreated control. Plant vigor was significantly increased by NAC at $500 \mathrm{mg} \mathrm{liter}^{-1}$ compared with the standard copper at the label dose of $630 \mathrm{mg} \mathrm{liter}^{-1}$ and the untreated control. Total fruit yield from treatment with NAC at 1,000 mg liter ${ }^{-1}$ was significantly greater than the standard copper at $630 \mathrm{mg} \mathrm{liter}^{-1}$ but not significantly different from the untreated control.

In field experiment 2, NAC at $1,000 \mathrm{mg} \mathrm{liter}^{-1}$ and NAC at $1,000 \mathrm{mg} \mathrm{liter}^{-1}+$ copper at $150 \mathrm{mg} \mathrm{liter}^{-1}$ significantly reduced the disease severity of bacterial spot compared with the standard copper at $630 \mathrm{mg} \mathrm{liter}^{-1}$ and the untreated control (Table 3). NAC at $1,000 \mathrm{mg} \mathrm{liter}^{-1}+$ copper at $150 \mathrm{mg} \mathrm{liter}^{-1}$ was the most effective treatment in reducing bacterial spot disease (by 42.9\%) among all treatments. In addition, plant vigor in these two treatments was significantly greater than copper at $630 \mathrm{mg} \mathrm{liter}^{-1}$ and the untreated control. In this field trial, the standard copper at a recommended dose of $630 \mathrm{mg} \mathrm{liter}^{-1}$ did not effectively control bacterial spot. Data of fruit yields were not collected in field experiment 2 due to the heavy infection with TYLCV during late stages of this field trial.

In field experiment 3, NAC at 1,000 $\mathrm{mg} \mathrm{liter}^{-1}+$ copper at $150 \mathrm{mg}$ liter $^{-1}$ was the only treatment that significantly reduced the disease severity of bacterial spot compared with the untreated control (Table 3). Plant vigor and fruit yields in all treatments were not significantly different from the untreated control.

\section{Discussion}

In this study, for the first time, we demonstrated the antibacterial activities of a small-molecule NAC against the copper-resistant $X$. perforans, the causal agent of bacterial spot of tomato in Florida. We report here that NAC alone was effective in reducing disease severity of bacterial spot of tomato under greenhouse conditions but not in the fields of south Florida. Improved efficacy of copper-based bactericides against $X$. perforans could be achieved by combining NAC with copper. Results obtained in this study indicated that the use of NAC could be an effective alternative strategy for managing copper-resistant $X$. perforans in tomato.

NAC has been a commonly used mucolytic agent to treat many human diseases in medicine (Deepmala et al. 2015; Dhouib et al. 2016). However, until recent years, limited information was available about the effects of NAC against plant-pathogenic bacteria in agriculture. The use of NAC in agriculture was first reported by Muranaka et al. (2013) to effectively control citrus variegated chlorosis caused by $X$. fastidiosa with the MIC of $6 \mathrm{mg} \mathrm{ml}^{-1}$. Picchi et al. (2016) described that NAC at $6 \mathrm{mg} \mathrm{ml}^{-1}$ had antibacterial activities against $X$. citri subsp. citri. These studies opened the door to new possibilities for the use of NAC as an antibacterial compound 
Table 2. Effect of N-acetylcysteine (NAC) and copper (Kocide 3000), alone and in combination, on bacterial spot of tomato in the greenhouse

\begin{tabular}{|c|c|c|c|c|}
\hline Treatment, concentration $\left(\mathrm{mg} \mathrm{liter}^{-1}\right)$ & Disease severity $(\%)^{\mathrm{w}}$ & Disease reduction, observed $(\%)^{\mathrm{x}}$ & Disease reduction, expected $(\%)^{y}$ & Difference $^{z}$ \\
\hline \multicolumn{5}{|l|}{ Experiment 1} \\
\hline \multicolumn{5}{|l|}{ NAC } \\
\hline 100 & $69.3 \pm 3.7 \mathrm{~b}$ & 14.8 & $\ldots$ & $\ldots$ \\
\hline 1,000 & $49.2 \pm 3.6 \mathrm{~cd}$ & 39.5 & $\ldots$ & $\ldots$ \\
\hline \multicolumn{5}{|l|}{ Copper } \\
\hline 150 & $68.7 \pm 3.1 \mathrm{~b}$ & 15.5 & $\ldots$ & $\ldots$ \\
\hline 300 & $52.7 \pm 4.8 \mathrm{c}$ & 35.2 & $\ldots$ & $\ldots$ \\
\hline \multicolumn{5}{|l|}{$\mathrm{NAC}+$ copper } \\
\hline $100+150$ & $47.3 \pm 3.7 \mathrm{~cd}$ & 41.8 & 48.5 & -6.7 \\
\hline $100+300$ & $41.3 \pm 3.4 \mathrm{~d}$ & 49.2 & 44.8 & +4.4 \\
\hline $1,000+150$ & $43.8 \pm 5.5 \mathrm{~cd}$ & 46.1 & 48.9 & -2.8 \\
\hline $1,000+300$ & $30 \pm 3.9 \mathrm{e}$ & 63.1 & 60.8 & +2.3 \\
\hline Control (water) & $81.3 \pm 2.2 \mathrm{a}$ & $\ldots$ & $\ldots$ & $\ldots$ \\
\hline \multicolumn{5}{|l|}{ Experiment 2} \\
\hline \multicolumn{5}{|l|}{ NAC } \\
\hline 100 & $42.7 \pm 4.0 \mathrm{~b}$ & 28.8 & $\ldots$ & $\ldots$ \\
\hline 1,000 & $26.3 \pm 4.0 \mathrm{~cd}$ & 56.2 & $\ldots$ & $\ldots$ \\
\hline \multicolumn{5}{|l|}{ Copper } \\
\hline 150 & $44 \pm 4.0 \mathrm{~b}$ & 26.7 & $\ldots$ & $\ldots$ \\
\hline 300 & $36.7 \pm 3.9 \mathrm{~b}$ & 38.8 & $\ldots$ & $\ldots$ \\
\hline \multicolumn{5}{|l|}{$\mathrm{NAC}+$ copper } \\
\hline $100+150$ & $35.3 \pm 3.5 b c$ & 41.2 & 47.8 & -6.6 \\
\hline $100+300$ & $24.3 \pm 2.7 \mathrm{~d}$ & 59.5 & 56.4 & +3.1 \\
\hline $1,000+150$ & $22.7 \pm 2.7 \mathrm{~d}$ & 62.2 & 67.9 & -5.7 \\
\hline $1,000+300$ & $18.7 \pm 3.7 \mathrm{~d}$ & 68.8 & 73.2 & -4.4 \\
\hline Control (water) & $60 \pm 3.4 \mathrm{a}$ & $\ldots$ & $\ldots$ & $\ldots$ \\
\hline \multirow{2}{*}{\multicolumn{5}{|c|}{$\begin{array}{l}\text { w Disease was rated by estimating the percentage of leaf area with bacterial lesions on those three inoculated compound leaflets of each plant at } 7 \text { to } 10 \text { days after } \\
\text { the inoculation. Data are expressed as means } \pm \text { standard error. Numbers in the same column followed by the same letters are not significantly different according } \\
\text { to Student-Newman-Keuls test }(P<0.05) \text {. }\end{array}$}} \\
\hline & & & & \\
\hline \multicolumn{5}{|c|}{$\begin{array}{l}\text { y Data were transformed to the percentage of reduction from the untreated control and the synergistic or antagonistic responses of the two treatments calculated } \\
\text { according to the Colby formula: } E=I_{\mathrm{L}}+I_{\mathrm{T}}-I_{\mathrm{L}} I_{\mathrm{T}} / 100 \text {, where } I_{\mathrm{L}} \text { is the percentage inhibition of growth by NAC at dose } C_{\mathrm{L}}, I_{\mathrm{T}} \text { is the percentage inhibition of } \\
\text { growth by copper at dose } C_{\mathrm{T}}(\text { Colby } 1967) \text {, and } E \text { is the expected percentage inhibition of growth by NAC }+ \text { copper at dose of } C_{\mathrm{L}}+C_{\mathrm{T}} \text {. When the expected } \\
\text { response is less than the observed, the combination is synergistic; when greater than observed, it is antagonistic. }\end{array}$} \\
\hline
\end{tabular}

Table 3. Effect of N-acetylcysteine (NAC) and copper (Kocide 3000) on bacterial spot of tomato in the field ${ }^{\mathrm{v}}$

\begin{tabular}{|c|c|c|c|c|c|}
\hline Treatment $\left(\mathrm{mg} \mathrm{liter}^{-1}\right)^{\mathrm{w}}$ & AUDPC, disease severity $(\%)^{x}$ & Disease reduction $(\%)$ & Vigor $^{y}$ & Yield $\left(\mathrm{kg} \mathrm{plant}^{-1}\right)^{\mathrm{z}}$ & Yield increase rate $(\%)$ \\
\hline \multicolumn{6}{|l|}{ Experiment 1} \\
\hline Control (water) & $84.3 \pm 4.5 \mathrm{a}$ & $\ldots$ & $3.0 \pm 0.3 \mathrm{~b}$ & $1.7 \pm 0.2 \mathrm{ab}$ & $\ldots$ \\
\hline Copper 630 & $63.8 \pm 4.6 \mathrm{~b}$ & 24.3 & $3.1 \pm 0.3 \mathrm{~b}$ & $1.2 \pm 0.2 \mathrm{~b}$ & -15.2 \\
\hline NAC 500 & $76.1 \pm 4.7 \mathrm{ab}$ & 9.7 & $4.0 \pm 0.3 \mathrm{a}$ & $1.8 \pm 0.2 \mathrm{ab}$ & 7.3 \\
\hline NAC 1,000 & $73.1 \pm 2.6 \mathrm{ab}$ & 13.3 & $3.6 \pm 0.2 \mathrm{ab}$ & $1.9 \pm 0.2 \mathrm{a}$ & 16.4 \\
\hline \multicolumn{6}{|l|}{ Experiment 2} \\
\hline Control (water) & $23.3 \pm 1.2 \mathrm{a}$ & $\ldots$ & $3.2 \pm 0.1 \mathrm{c}$ & $\ldots$ & $\ldots$ \\
\hline Copper 630 & $26.9 \pm 2.3 \mathrm{a}$ & -15.22 & $2.5 \pm 0.2 \mathrm{~d}$ & $\ldots$ & $\ldots$ \\
\hline NAC 1,000 & $18.9 \pm 1.4 \mathrm{~b}$ & 19.03 & $3.7 \pm 0.1 \mathrm{~b}$ & $\ldots$ & $\ldots$ \\
\hline NAC $1,000+$ copper 150 & $13.3 \pm 1.1 \mathrm{c}$ & 42.86 & $4.2 \pm 0.1 \mathrm{a}$ & $\ldots$ & $\ldots$ \\
\hline \multicolumn{6}{|l|}{ Experiment 3} \\
\hline Control (water) & $673.0 \pm 38.8 \mathrm{a}$ & $\ldots$ & $3.8 \pm 0.2 \mathrm{a}$ & $1.3 \pm 0.1 \mathrm{a}$ & $\ldots$ \\
\hline Copper 630 & $568.0 \pm 21.6 \mathrm{ab}$ & 15.6 & $4.3 \pm 0.1 \mathrm{a}$ & $1.3 \pm 0.2 \mathrm{a}$ & 0 \\
\hline NAC 1,000 & $633.6 \pm 31.7 \mathrm{a}$ & 5.9 & $3.9 \pm 0.2 \mathrm{a}$ & $1.3 \pm 0.1 \mathrm{a}$ & 0 \\
\hline NAC $1,000+$ copper 150 & $516.3 \pm 44.2 b$ & 23.3 & $3.8 \pm 0.3 \mathrm{a}$ & $1.3 \pm 0.1 \mathrm{a}$ & 0 \\
\hline
\end{tabular}

$\checkmark$ Data are expressed as means \pm standard error. Numbers in the same column followed by the same letters are not significantly different according to StudentNewman-Keuls test $(P<0.05)$.

${ }^{w}$ Treatments consisted of a water control, copper at $630 \mathrm{mg} \mathrm{liter}^{-1}$ (Copper 630), NAC at NAC at 500 or 1,000 mg liter ${ }^{-1}$ (NAC 500 or NAC 1,000, respectively), and copper at $150 \mathrm{mg} \mathrm{liter}^{-1}$ (copper 150).

$\mathrm{x}$ Disease was assessed by estimating the percentage of bacterial spot lesions on leaf surface 10 days after the inoculation with Xanthomonas perforans. For experiments 1 and 3, all plants in the field plots were rated for foliar disease severity three and five times, respectively, and area under the disease progress curve (AUDPC) over time was calculated for the field data using the trapezoidal method (Jeger 2004). For experiment 2, due to heavy infection of tomato yellow leaf curl virus (TYLCV), foliar disease severity was rated once and disease severity was provided. Data of fruit yields were not collected in experiment 2 due to the heavy infection with TYLCV during late stages of this field trial.

y Vigor of the plant seedlings was rated based on a 1 -to- 5 scale, where $5=$ vigorous growth, $4=$ slight yellowing and a little short, $3=$ more yellowing and shorter, and 2 and 1 = growing much more poorly than normal.

$\mathrm{z}$ Mature green fruit were harvested according to the Florida tomato production standards. 
to control plant-pathogenic bacteria. As a small-molecule compound, NAC is relatively easy to degrade in the environment, making it more sustainable to be used in agriculture compared with other conventional products (Muranaka et al. 2013). In addition, $\mathrm{NAC}$ is inexpensive and nontoxic, providing greater safety for the environment and applicators (Misra et al. 2004; Muranaka et al. 2013).

Our in vitro experiments demonstrated that the MIC of NAC against the resistant $X$. perforans was $2,048 \mathrm{mg} \mathrm{liter}^{-1}$. This is similar to previous results indicating that NAC at $2,500 \mathrm{mg} \mathrm{liter}^{-1}$ suppressed the growth of $X$. citri subsp. citri (Picchi et al. 2016). In another study, the MIC of NAC against $X$. fastidiosa was $6,000 \mathrm{mg}$ $\operatorname{liter}^{-1}$ (Muranaka et al. 2013). Such discrepancies could be associated with different experimental setups such as different types of bacteria and the initial rate of inoculation. Actually, the concentrations of NAC used on plants were much lower than those for the treatments against human bacterial diseases, which were above 10,000 mg li$\operatorname{ter}^{-1}$ (Quah et al. 2012; Zhao and Liu 2010). Moreover, in this study, we found that adding copper 6,9 , and $12 \mathrm{~h}$ after the application of NAC decreased the MIC of copper against the copper-resistant $X$. perforans. Other studies reported similar observations: that NAC at $6,000 \mathrm{mg} \mathrm{liter}^{-1}$ in combination with copper at $3.5 \mathrm{mg} \mathrm{liter}^{-1}$ was the best combination to completely inhibit the $X$. citri growth in vitro (Picchi et al. 2016). It was reported that the bacterial cells were more susceptible to copper after addition of NAC because NAC interfered with the formation of biofilm by $X$. citri under epiphytic conditions (Picchi et al. 2016). The combined application of NAC with copper is appealing because it may increase copper activity and efficacy in the control of copper-resistant $X$. perforans.

Results from our greenhouse experiments were similar to those of in planta experiments described by Muranaka et al. (2013), which suggested that the application of NAC reduced disease symptoms and lowered $X$. fastidiosa populations in sweet orange. Moreover, according to the Colby formula, NAC at $100 \mathrm{mg} \mathrm{liter}^{-1}+$ copper at $300 \mathrm{mg} \mathrm{liter}^{-1}$ consistently showed a synergistic effect in our greenhouse experiments. The combination of NAC with copper enhanced the bactericidal activity of copper against $X$. perforans. Other studies also showed that NAC at $6,000 \mathrm{mg} \mathrm{liter}^{-1}$ induced osmotic stress in sweet orange (Muranaka et al. 2013).

In field experiments 2 and 3 , the standard copper at the recommended dose of $630 \mathrm{mg} \mathrm{liter}{ }^{-1}$ was ineffective against bacterial spot, which is in agreement with the conclusion that all of the $X$. perforans strains isolated from some commercial tomato fields in Florida were copper resistant (Horvath et al. 2012). Similarly, Abrahamian et al. (2019) recently reported that copper application resulted in the variable efficacy in $X$. perforans management in transplant and field production. Although application of copperbased products has played an important role in management of bacterial spot for a long time, the continued use of copper has prompted the development of copper-resistant strains (Behlau et al. 2012). Moreover, frequent and continuous use of copper-based products has led to the exacerbation of side effects to the environment due to the accumulation of copper in soils and groundwater (Wuana and Okieimen 2011). Interestingly, it has been reported that NAC mitigated heavy metals accumulation in plant roots and enhanced growth of the plants exposed to heavy metals, including copper and cadmium (Colak et al. 2019; Sun et al. 2014). Further research needs to be conducted to investigate the effect of NAC on reducing copper accumulation in Florida.

Also noteworthy is the fact that, due to heavy infection of TYLCV, the bacterial spot disease was only rated once for field experiment 2 . However, both NAC at $1,000 \mathrm{mg} \mathrm{liter}^{-1}$ and NAC at 1,000 mg liter ${ }^{-1}$ + copper at $150 \mathrm{mg} \mathrm{liter}^{-1}$ showed significant effects on disease severity reduction compared with the untreated control. Furthermore, the combination treatment of NAC at $1,000 \mathrm{mg} \mathrm{liter}^{-1}+$ copper at $150 \mathrm{mg} \mathrm{liter}^{-1}$ significantly improved the disease control of NAC at $1,000 \mathrm{mg} \mathrm{liter}^{-1}$ and copper. In the repeated experiment 3 , the effects of NAC at $1,000 \mathrm{mg} \mathrm{liter}^{-1}$ and NAC at $1,000 \mathrm{mg} \mathrm{liter}^{-1}+$ copper at $150 \mathrm{mg} \mathrm{liter}^{-1}$ on reduction in bacterial spot disease severity and AUDPC confirmed the results from experiment 2. Many biotic and abiotic factors may affect efficacies of pesticides under field conditions. Therefore, further field trials are needed to verify the management effectiveness of NAC under various environmental niches.

The antimicrobial activities of NAC and its associated mechanisms have been documented (Muranaka et al. 2013; Picchi et al. 2016). Biofilm formation by plant bacterial pathogens is important in the development of diseases because it affects the epiphytic bacterial survival on leaves, further infection, and virulence in plants (Rigano et al. 2007). Li and Wang (2014) reported that D-leucine and 3-indolylacetonitrile inhibited the biofilm formation of $X$. citri, making it more susceptible to copper. Similarly, Worthington et al. (2012) demonstrated that 2-aminoimidazole decreased the resistance of $X$. euvesicatoria to copper by impairing biofilm formation. We hypothesized that NAC suppressed the copper-resistant $X$. perforans on tomato plants by inhibiting the formation of biofilm, thus enhancing its susceptibility to lower rates of copper. However, further research is needed to determine the effect of NAC on biofilm formation of $X$. perforans.

Overall, results from our study demonstrated that NAC showed antibacterial activities against copper-resistant $X$. perforans, making it a potentially new and sustainable strategy in management of bacterial spot of tomato, especially when it was applied in combination with copper. These findings extend the novel use of NAC to tomato against $X$. perforans, indicating that application of NAC in agriculture could be an effective method for management of copper-resistant $X$. perforans. Further studies need to be conducted to investigate the antibacterial mechanisms for NAC against copper-resistant $X$. perforans, including the interference with biofilm formation.

\section{Acknowledgments}

We thank Y. Wang for her technical assistance in the greenhouse and field studies.

\section{Literature Cited}

Abrahamian, P., Jones, J. B., and Vallad, G. E. 2019. Efficacy of copper and copper alternatives for management of bacterial spot on tomato under transplant and field production. Crop Prot. 126:104919.

Basim, H., Minsavage, G. V., Stall, R. E., Wang, J., Shanker, S., and Jones, J. B. 2005. Characterization of a unique chromosomal copper resistance gene cluster from Xanthomonas campestris pv. vesicatoria. Appl. Environ. Microbiol. 71: 8284-8291.

Behlau, F., Canteros, B. I., Jones, J. B., and Graham, J. H. 2012. Copper resistance genes from different xanthomonads and citrus epiphytic bacteria confer resistance to Xanthomonas citri subsp. citri. Eur. J. Plant Pathol. 133:949-963.

Clinical and Laboratory Standards Institute. 2008. Performance Standards for Antimicrobial Susceptibility Testing: Eighteenth Informational Supplement CLSI Document M100-S18. CLSI, Wayne, PA, U.S.A.

Colak, N., Torun, H., Gruz, J., Strnad, M., and Ayaz, F. A. 2019. Exogenous Nacetylcysteine alleviates heavy metal stress by promoting phenolic acids to support antioxidant defence systems in wheat roots. Ecotoxicol. Environ. Saf. 181:49-59.

Colby, S. 1967. Calculating synergistic and antagonistic responses of herbicide combinations. Weeds 15:20-22.

Deepmala, Slattery, J., Kumar, N., Delhey, L., Berk, M., Dean, O., Spielholz, C., and Frye, R. 2015. Clinical trials of N-acetylcysteine in psychiatry and neurology: A systematic review. Neurosci. Biobehav. Rev. 55:294-321.

Dhouib, I. E., Jallouli, M., Annabi, A., Gharbi, N., Elfazaa, S., and Lasram, M. M 2016. A minireview on $\mathrm{N}$-acetylcysteine: An old drug with new approaches. Life Sci. 151:359-363.

Freeman, J. H., Vallad, G. E., and Dittmar, P. J. 2016. Vegetable Production Handbook of Florida 2016-2017. IFAS Extension University of Florida, Gainesville, FL, U.S.A.

Gisi, U. 1996. Synergistic interaction of fungicides in mixtures. Phytopathology 86:1273-1279.

Han, Y., Wang, Y., Tombosa, S., Wright, S., Huffman, J., Yuen, G., Qian, G., Liu, F., Shen, Y., and Du, L. 2015. Identification of a small molecule signaling factor that regulates the biosynthesis of the antifungal polycyclic tetramate macrolactam HSAF in Lysobacter enzymogenes. Appl. Microbiol. Biotechnol. 99:801-811.

Horvath, D. M., Stall, R. E., Jones, J. B., Pauly, M. H., Vallad, G. E., Dahlbeck, D., Staskawicz, B. J., and Scott, J. W. 2012. Transgenic resistance confers effective field level control of bacterial spot disease in tomato. PLoS One 7:e42036.

Jeger, M. J. 2004. Analysis of disease progress as a basis for evaluating disease management practices. Annu. Rev. Phytopathol. 42:61-82. 
Jones, J. B., Jackson, L. E., Balogh, B., Obradovic, A., Iriarte, F. B., and Momol, M. T. 2007. Bacteriophages for plant disease control. Annu. Rev. Phytopathol. 45:245-262.

Jones, J. B., Lacy, G. H., Bouzar, H., Stall, R. E., and Schaad, N. W. 2004. Reclassification of the Xanthomonads associated with bacterial spot disease of tomato and pepper. Syst. Appl. Microbiol. 27:755-762.

Lamichhane, J. R., Osdaghi, E., Behlau, F., Köhl, J., Jones, J. B., and Aubertot, J. N. 2018. Thirteen decades of antimicrobial copper compounds applied in agriculture. A review. Agron. Sustain. Dev. 38:28.

Li, J., and Wang, N. 2014. Foliar application of biofilm formation-inhibiting compounds enhances control of citrus canker caused by Xanthomonas citri subsp. citri. Phytopathology 104:134-142.

Liu, Q., Zhang, S., Huang, Y., and Jones, J. B. 2019. Evaluation of a small molecule compound 3-indolylacetonitrile for control of bacterial spot on tomato. Crop Prot. 120:7-12.

Louws, F. J., Wilson, M., Campbell, H. L., Cuppels, D. A., Jones, J. B., Shoemaker, P. B., Sahin, F., and Miller, S. A. 2001. Field control of bacterial spot and bacterial speck of tomato using a plant activator. Plant Dis. 85: 481-488.

Misra, D., Leibowitz, K., Gowda, R. M., Shapiro, M., and Khan, I. A. 2004. Role of $\mathrm{N}$-acetylcysteine in prevention of contrast-induced nephropathy after cardiovascular procedures: A meta-analysis. Clin. Cardiol. 27:607-610.

Muranaka, L. S., Giorgiano, T. E., Takita, M. A., Forim, M. R., Silva, L. F., Coletta-Filho, H. D., Machado, M., and de Souza, A. A. 2013. NAcetylcysteine in agriculture, a novel use for an old molecule: Focus on controlling the plant-pathogen Xylella fastidiosa. PLoS One 8:e72937.

Paret, M. L., Vallad, G. E., Averett, D. R., Jones, J. B., and Olson, S. M. 2013. Photocatalysis: Effect of light-activated nanoscale formulations of $\mathrm{TiO}_{2}$ on Xanthomonas perforans and control of bacterial spot of tomato. Phytopathology 103:228-236.

Picchi, S. C., Takita, M. A., Coletta-Filho, H. D., Machado, M. A., and de Souza, A. A. 2016. N-acetylcysteine interferes with the biofilm formation, motility and epiphytic behaviour of Xanthomonas citri subsp. citri. Plant Pathol. 65: 561-569.

Pietrzak, U., and McPhail, D. C. 2004. Copper accumulation, distribution and fractionation in vineyard soils of Victoria, Australia. Geoderma 122:151-166.

Potnis, N., Timilsina, S., Strayer, A., Shantharaj, D., Barak, J. D., Paret, M. L., Vallad, G. E., and Jones, J. B. 2015. Bacterial spot of tomato and pepper: Diverse Xanthomonas species with a wide variety of virulence factors posing a worldwide challenge. Mol. Plant Pathol. 16:907-920.
Qiao, K., Liu, Q., Huang, Y., Xia, Y., and Zhang, S. 2020. Management of bacterial spot of tomato caused by copper-resistant Xanthomonas perforans using a small molecule compound carvacrol. Crop Prot. 132:105114.

Quah, S., Wu, S., Lui, J., Sum, C., and Tan, K. 2012. N-acetylcysteine inhibits growth and eradicates biofilm of Enterococcus faecalis. J. Endod. 38:81-85.

Rigano, L., Siciliano, F., Enrique, R., Sendín, L., Filippone, P., Torres, P., Qüesta, J., Dow, J., Castagnaro, A., Vojnov, A., and Marano, M. 2007. Biofilm formation, epiphytic fitness, and canker development in Xanthomonas axonopodis pv. citri. Mol. Plant-Microbe Interact. 20:1222-1230.

Shi, Y., Hu, X., Cheng, J., Zhang, X., Zhao, F., Shi, W., Ren, B., Yu, H., Yang, P., Li, Z., Liu, Q., Duan, X., Fu, X., Zhang, J., Wang, J., and Ao, Y. 2019. A small molecule promotes cartilage extracellular matrix generation and inhibits osteoarthritis development. Nat. Commun. 10:1914.

Singh, A., Gupta, R., Tandon, S., and Pandey, R. 2018. Anti-biofilm and antivirulence potential of 3,7-dimethyloct-6-enal derived from Citrus hystrix against bacterial blight of rice caused by Xanthomonas oryzae pv. oryzae. Microb. Pathog. 115:264-271.

Stall, R. E., Jones, J. B., and Minsavage, G. V. 2009. Durability of resistance in tomato and pepper to xanthomonads causing bacterial spot. Annu. Rev. Phytopathol. 47:265-284.

Sun, H., Zhang, X., He, X., Ahmed, I. M., Cao, F., Zhang, G., and Wu, F. 2014. Nacetyl-cysteine alleviates $\mathrm{Cd}$ toxicity and reduces $\mathrm{Cd}$ uptake in the two barley genotypes differing in Cd tolerance. Plant Growth Regul. 74:93-105.

Vallad, G., Timilsina, S., Adkison, H., Potnis, N., Minsavage, G., Jones, J., and Goss, E., 2013. A recent survey of Xanthomonads causing bacterial spot of tomato in Florida provides insights into management strategies. Pages 25-27 in: Proc. 2013 Fla. Tomato Inst. M. Ozores-Hampton and C. Snodgrass, eds. Naples, FL, U.S.A.

Worthington, R. J., Rogers, S. A., Huigens, R. W., III, Melander, C., and Ritchie, D. F. 2012. Foliar-applied small molecule that suppresses biofilm formation and enhances control of copper-resistant Xanthomonas euvesicatoria on pepper. Plant Dis. 96:1638-1644.

Wuana, R. A., and Okieimen, F. E. 2011. Heavy metals in contaminated soils: A review of sources, chemistry, risks and best available strategies for remediation. ISRN Ecol. 2011:1-20.

Xie, S., Zang, H., Wu, H., Uddin Rajer, F., and Gao, X. 2018. Antibacterial effects of volatiles produced by Bacillus strain D13 against Xanthomonas oryzae pv. oryzae. Mol. Plant Pathol. 19:49-58.

Zhao, T., and Liu, Y. 2010. N-acetylcysteine inhibit biofilms produced by Pseudomonas aeruginosa. BMC Microbiol. 10:140. 